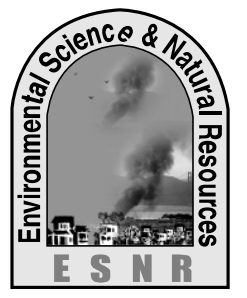

J. Environ. Sci. \& Natural Resources, 6(2): 109 -114, 2013

ISSN 1999-7361

\title{
Causes of Deforestation and Conservation of Madhupur Sal Forest in Tangail Region
}

\author{
M. N. Hossain ${ }^{1}$, M. Rokanuzzaman ${ }^{2}$, M. A. Rahman ${ }^{1}$, M. Bodiuzzaman ${ }^{1}$ and M. A. Miah ${ }^{2}$ \\ ${ }^{1}$ Department of Environmental Science and Resource Management, Mawlana Bhashani Science and \\ Technology University, Santosh, Tangail \\ ${ }^{2}$ Department of Environmental Science, Bangladesh Agricultural University Mymensingh-22O2
}

\begin{abstract}
Over the past few decades deforestation has become the issue of global concern for its rapid reduction of biodiversity. The tropical moist deciduous Sal forest ecosystem of central Bangladesh is currently in a critical situation. Destructive anthropogenic and natural impacts coupled with overexploitation of forest resources have caused severe damage to the forest ecosystem. Due to rubber monoculture, expanding commercial fuel wood plantations \& expanding agriculture, illegal cutting, encroachment of forest areas, and illegal poaching of wildlife, the Sal forest is losing biodiversity alarmingly. The study is based on intensive literature survey and tries to explore the overall deforestation situation and conservation practices for Madhupur Sal forest that comprises about $5 \%$ of the total forests in Bangladesh. The level of destruction of the natural Sal forest has pushed the forest-dwelling indigenous Garo community into cash crop production, forcing them to move away from their traditional subsistence economy. Now we need to address a joint conservation and improved management plan of the forest resources use. Thus all kinds of military establishments, construction of roads and highways for military purposes should be avoided and a policy of planned industrialization should be adopted to mitigate the adverse effect of industrialization. Findings of the study will help to identify the causes of deforestation and conservation of Madhupur Sal forest and also in other national parks in Bangladesh which ultimately conserve the biodiversity and help to maintain natural balance.
\end{abstract}

Key Words: Conservation, Deforestation, Forest

\section{Introduction}

Bangladesh is a forest poor country though its looks luxuriant green. The forest cover has shrunk to merely $6 \%$ today from about $18 \%$ in 1972 . This has serious consequences for the forest dwelling communities (Gain, 2002). Historic Madhupur Garh is a pleasant forest area located in central Bangladesh. It lies predominantly in the Pleistocene terrace area of Tangail District, which is found between the River Banar in the east and Bangshai in the west (Latif, 1983) Madhupur forest is a tropical, moist, and deciduous type of forest. MNP is located at $24^{0} 45^{\prime} \mathrm{N}$ Latitude and $90^{\circ} 05^{\prime} \mathrm{E}$ Longitude, on the TangailMymensingh main road, encompass a Gazette notified area of 8,436 ha. . Actually this forest is present in low land and flood plain based area. In our country, only this forest contains pure Sal (Shoria robusta) tree. The Park was established by the Forest Department in 1962 and formally notified in Gazette in 1982. At present, the tract of Madhupur forest (MF) consists an area of 45,565.18 acres out of which 2,525 acres are reserved and 4,304 acres land are under the process to be declared as reserved forest. For the purpose of biodiversity conservation, Government declared Madhupur Garh which is also known as 'Madhupur National Park' comprising an area of 20,837.23 acres by a gazette, notifying on 24th February 1982. Out of that, 20,244.23 acres are under Madhupur upazila of Tangail district and 593.00 acres are under Muktagacha upazila of Mymensingh district (Ahmed, 2008).
Geomorphologically, Madhupur Garh is a part of the Madhupur Tract and topographically it is raised a few metres above the level of the surrounding flood plains (Khaleque, 1992; Burling, 1997). The natural and climatic condition of this region is very much suitable for growing pure Sal tree. Besides, this forest contains a huge variety of floral composition, different type of mammals, reptiles, avis and amphibians. The major part of this forest is covered with Sal tree. It houses a total of 176 species of plants including 73 trees, 22 shrubs, 1 palm, 8 grasses, 27 climbers and 45 herbs. Besides, there are a number of exotic species planted in the national park area. Existing faunal composition includes 21 species of mammals, 140 species of birds and 29 reptiles in this park (Gain, 2004).

Today, most of the forestland in Madhupur has been denuded, degraded or encroached upon or taken over for the commercial production of pineapples or bananas or the industrial plantation of rubber or exotic fuel-wood species. The Garos have long been involved in pineapple production, but in recent years banana monoculture has become very popular among them, and it is changing the typical land-use pattern of Madhupur very rapidly (Gain, 2002). Hence the study was conducted with the activities: (1) To explore the causes of deforestation, (2) To find out causes which is responsible to degrade forest resource, (3) To assess existing conservation strategies. 


\section{Study Methodology}

\section{Selection of the study area}

The study is confined only to the part of Madhupur Garh forest which is placed under Madhupur Upazila of Tangail District. It should be mentioned that the last remains of the sal forest are mainly found in the Arankhola Union Parishad of Madhupur Upazila. For this reason, the questionnaire survey was conducted of the Garo villages of Arankhola Union. Moreover, to gain in-depth knowledge of the area and the community, out of the ten Garo villages, three Chunia, Bhutia and Pirgacha - were selected for intensive study.

\section{Sampling}

Sampling is a definite plan for obtaining information from a given population. Thus the population of sampling area were known and the data were collected by simple random sampling technique. The area was selected such as Aronkhola union of Madhupur Thana of Tangail District. This union was selected randomly. The population was selected randomly from the union. There used simple random sampling to collect sample from population. The sample was selected according to the residence of a specific region. The total number of the respondent was 100 people were selected from a specific union and this respondent was selected randomly. The respondent was selected from all age, sex, and religion and there was no discrimination in the collection of information from the respondents.

\section{Data Collection}

The research is based on primary and secondary information under direct supervision of supervisor. Different methodology like- Interview with local people, questionnaire survey, FGD was applied for the data collection. Secondary data have been collected by making an overview of prior research by universities, books, journals, periodicals, and various documents of the BBS and the Department of Forest and Environment, local forest offices and NGOs such as SEHD. Both primary and secondary data was used for the study. In order to collect primary data of a questionnaire survey was conducted in the Madhupur area at the preliminary stage of the study which was followed by a random selection of 100 indigenous Garo and Bengali respondent.

\section{Data Processing and analysis}

After accumulating numerous data and information from field survey the first step was to ensure the validity and reliability of the data and edited the data to improve its quality. SPSS program of the computer was used to process and analyze the data. For the purpose of convenience and better presentation, the findings from site visits were clustered in tabular form, percentage and graph texts, tables.

\section{Results and Discussion}

\section{Location of the respondents}

The data were collected from the Residential area (56\%), Non-residential area (28\%), Street and Terminal area $(16 \%)$ of the Union of Arunkhola in Modhupur, Tangail. For collecting data survey method was used.

\section{Characteristics of the respondents}

The study revealed that, most of the respondents (62 $\%)$ are male and (38\%) are female.

\section{Age of the respondents}

To conduct the study, respondents were collected from four tiers of age group mentioning bellow 20 years $8 \%, 21-30$ years $26 \%, 31-40$ years $46 \%$, and $41-50$ years $15 \%$ and above 50 years $5 \%$. So, we have seen that most of the respondents were older.

\section{Education level of the respondents}

The study indicates that, illiterates are of $11 \%$, less $5^{\text {th }}$ standards are of $28 \%$, most of the respondents $42 \%$ are of $6^{\text {th }}-9^{\text {th }}$ standards. Only $12 \%$ and $7 \%$ respondents of the study have completed S.S.C and H.S.C education respectively.

\section{Occupation of the respondents}

The study indicates that, in most of the respondents $55 \%$ are farmer, day labor $29 \%$ followed by service holder 3\% and 7\% respondents are of housewife and others $6 \%$.

\section{Income of the respondents}

The study found that, most of the respondent's monthly income is $3000-5000$ BDT (56\%) followed by $6000-10000$ BDT (21\%), and 3000 below (14\%) respondents. The highest income 11000 to 15000 BDT $(9 \%)$ respondents are respectively.

\section{Causes of deforestation and degradation of Modhupur Sal Forest}

\section{Wood collection for cooking purpose}

Fig. 1. Shows that, most of the respondents (59\%) use 6-10 kg wood for their daily cooking purpose, followed by $26 \%$, use $1-5 \mathrm{~kg}$ and $15 \%$ respondents 
use $11-15 \mathrm{~kg}$ wood that they collect from existing forest.

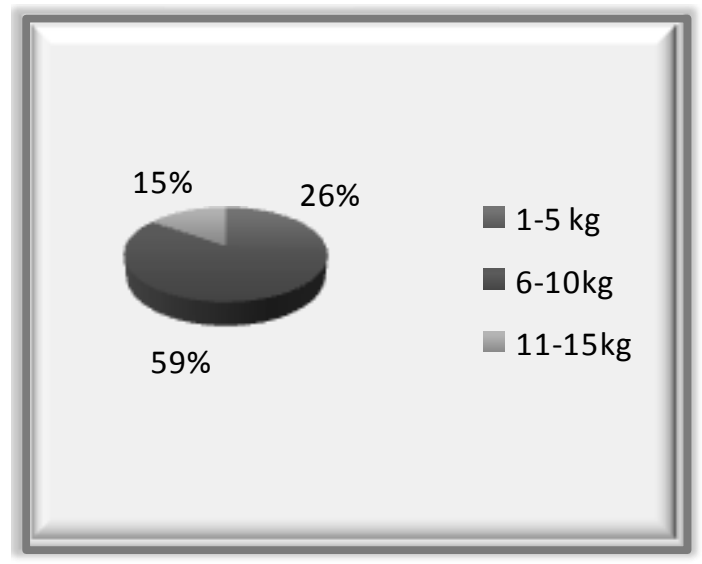

Fig. 1. Wood collection for cooking purpose (daily)

\section{Agriculture Activities}

The study found that, the major causes of deforestation occur by the agricultural activities. In Modhupur forest, the deforestation are accelerated by such of this activities were the cash crops activities $(62 \%)$, corn producing activities $(21 \%)$, and others (17\%) (Fig. 2).

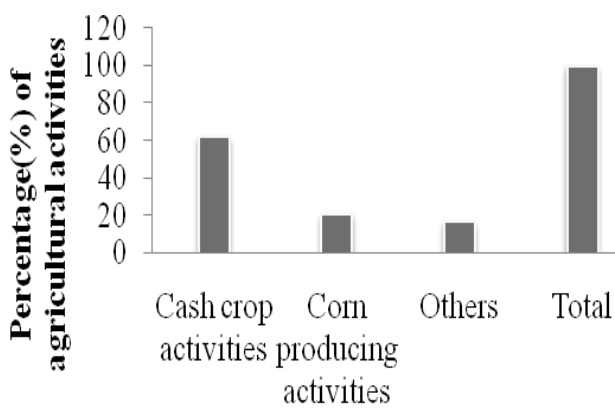

Level of agricultural activities

Fig. 2. Show that agriculture activities

\section{Cattle ranching in the forest area}

The study found that, cattle ranching were one of the major causes of deforestation. In the study, the most of the respondent (89 percent) revealed that the different types of cattle are ranched here. The most of the respondent $(83 \%)$ mind that the type of the cattle ranching is domestic animal and followed by (17\%) by wild animal.

\section{Forest fire}

Forest fire is the major causes of the degradation and deforestation of the forest. The study shows that, the most of the respondents (67\%) response that smoking, followed by $(12 \%)$ response that naturally occurring in the summer and $(21 \%)$ of the respondents think that the fire occurred intentionally by illegal human induced activities and which is the major issue of deforestation.

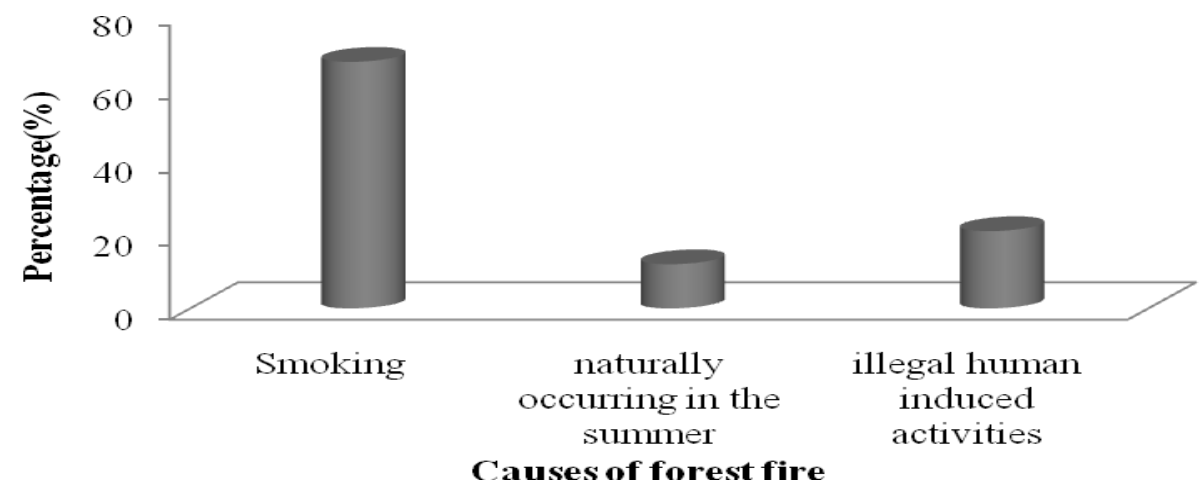

Fig. 3. Causes of forest fire

\section{Wood collection for development activities}

The study found that, the most of the wood collected from the forest for the use of development purposes. The study revealed that (54\%) woods used by Shaw mill for the development activities, followed by Brick field (29\%) and others (17\%) in fig 4. 


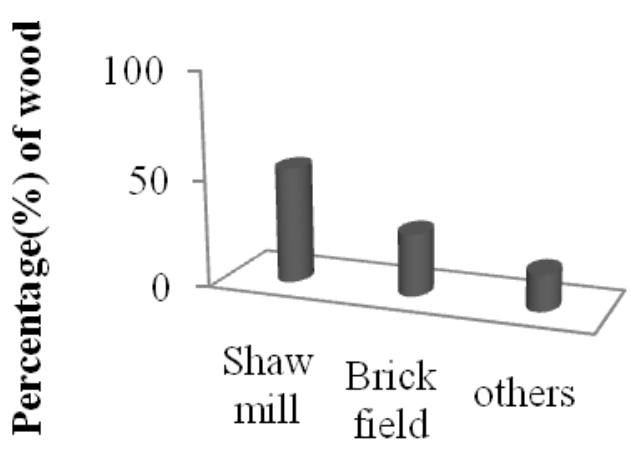

\section{Ievel of wood collection}

Fig. 4. Wood collection for development activities (daily)

\section{People's livelihood depends on the forest}

The forest is the main sources of livelihood for the greater majority of the poor people who lived in the surrounding forest area. They collect honey, leaf and tree branches for cooking and sometimes they cut trees to meet their daily financial demand in fig 5 .

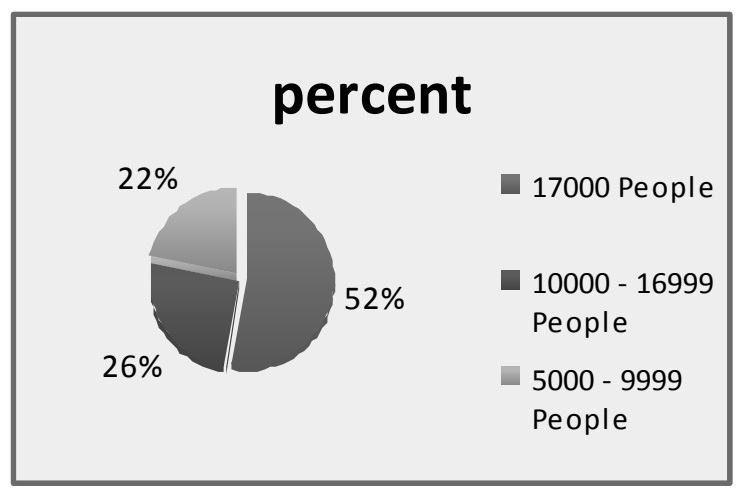

Fig. 5. Livelihood depends on the forest.

\section{Effect of exotic species}

Exotic species is another cause of environmental degradation because they affect the soil quality of the forest. During the monoculture of pineapple, banana and mixed culture of acacia, eucalyptus and pineapple, banana the farmer used more fertilizer for more production.

Table 1. Effect of exotic plant species according to respondents

\begin{tabular}{|c|c|}
\hline Effect of exotic plant species & Percent $(\%)$ \\
\hline Infiltration much Water & 23 \\
Dry soil & 19 \\
Loss of fertility & 58 \\
Total & 100 \\
\hline
\end{tabular}

Table 2. Status of Resources (Tick mark)

\begin{tabular}{|c|c|c|c|c|}
\hline \multirow[t]{2}{*}{ Resource } & \multirow[t]{2}{*}{ Name of Resource } & \multicolumn{3}{|c|}{ Status of forest } \\
\hline & & Increase & $\begin{array}{l}\text { No } \\
\text { change }\end{array}$ & Decrease \\
\hline Trees & $\begin{array}{l}\text { Sal, Amlochi, Hortoki, Chapalish, Ajuli. Shimul, Tendu, } \\
\text { Kodom, Bamboo, Asoth, Litchi, Mango, Amlaci, Neem, } \\
\text { Joyna, Polash, Jam, Jarul, Shiduri, Bohera, Gadila, } \\
\text { Gutum, Koroi. }\end{array}$ & & & $\sqrt{ }$ \\
\hline Flowers & Cactus, Asmalota, & & & $\sqrt{ }$ \\
\hline Fruits & Pineaple, Papaya, Banana, Amloki, & $\sqrt{1}$ & & \\
\hline Animals & $\begin{array}{l}\text { Deer, lizard, monkey, fox, wild cock, squirrel, lemur, } \\
\text { snake, meso bagh and wild cat, }\end{array}$ & & & $\sqrt{ }$ \\
\hline Birds & $\begin{array}{l}\text { Doel, Tuntuni, Seven Sister, Bulbuli, Crain, Shalik, } \\
\text { Cuckoo, Dahuk, Dove, Pigion, Parrot, Bat and Babui. }\end{array}$ & & & $\sqrt{ }$ \\
\hline Insects & Butter Fly, Cutter Filler, Dragon Fly, Ant. & & & $\sqrt{ }$ \\
\hline $\begin{array}{l}\text { Medicin- } \\
\text { al plants }\end{array}$ & $\begin{array}{l}\text { Shoti, Kuch, Bashok, Shorpogonda, Ulotkombol, } \\
\text { Shotomoli, Arjun,Lozzaboti }\end{array}$ & & & $\sqrt{ }$ \\
\hline
\end{tabular}




\section{Discussions}

Forestry is a sub-sector of agriculture in Bangladesh, which makes a contribution to the national economy and is supposed to contribute to ecological stability. From the immediate causes we can find the remote and underlying causes of deforestation and forest degradation in Bangladesh. The Tangail-Mymensingh highway, built during the British colonial period, opened the dark dense Sal forest to outsides of the first time. Over time, the developing transportation network through the Modhupur region has played a significant role in the over exploitation of forest resources, the destruction of biodiversity as well as the expansion of the commercial economy. Since 1950s, the formal ban on jhum cultivation, the Garos has engaged themselves in cash-crop production. Now-a-days, among the many cash crops, the production of bananas in monoculture form has raised many questions among the environment-conscious people. So the initiatives from both the government and non-government sectors should be undertaken in order to monitor the effects and impacts of this development. The involvement of local communities in preventing over-exploitation and poaching is essential to long-term conservation of forest resources. Finally a separate national body or institution is fundamental to ensure conservation; sustainable use and equitable sharing of benefits arisen from forest.

\section{Recommendations}

1. Forest management should be modernized through forest master plans, acts, policies to include local participation.

2. To stop the destruction of biodiversity by the project of social forestry.

3. To stop the plantation of exotic species harmful to the original species.

4. To stop the use of pesticides and hormones in the banana and pineapple plantation, that reduced the soil fertility.

5. To improvement in the income and livelihoods of people living in and around forest areas.

6. To increase participation of ethnic group in social forestry program.

7. In order to mitigate the adverse effect of development activities on forest, a policy of planned industrialization should be adopted that would avoid encroachment on forest land.

\section{References}

Ahmed, A. I. M. U. 2008. Underlying Causes of Deforestation and Forest Degradation in Bangladesh. Professor, Department of Sociology, University of Dhaka, 6-21pp.

Ahmad, M. 1986. Forestry Situation in Bangladesh: Move towards disaster.

Choudhury, J. K. 2001. Does Forestry Pay in Bangladesh? Lessons from ADB's Forestry Sector.

Dey, S. 2007. The commercialisation of the indigenous economy and its impact on the environment of Modhupur Garh, Bangladesh. Int. J. Green Economics, Vol. 1, Nos. 3/4, pp.465-477.

Dey, S. 2004. Degrading forest environment and local Garo females in Modhupur Garh, Bangladesh', Unpublished M. Phil diss. Department of Geography and Environment, University of Dhaka.

Gain, P. 2002. Bangladesh Environment facing the $21^{\text {st }}$ Century. Society for Environment and Human Development (SHED), ( $2^{\text {nd }}$ edition), pp-71-103.

Gain, P. 2004. Modhupur Forest. Demise Is Imminent. Society for Environment and Human Development (SEHD).

Gain, P. 1998. The last forests of Bangladesh. Society for Environment and Human Development (SEHD).

Hirakuri, S. R. 2003. Can Law Save the Forests? Lessons from Finland and Brazil. CIFOR. Bogor, Indonesia, 120 pp.

Khaleque, T. M. K. 1992. People, forests and tenure: the process of land and tree tenure change among the Garo of Madhupur Garh forest, Bangladesh', Doctoral diss., Department of Forestry, Michigan State University.

Landell-Mills, N. and Porras, I. T. 2002. Silver bullet or fools' gold? A global review of markets for forest environmental services and their impact on the poor. IIED, London, $254 \mathrm{pp}$.

Latif, M. A. 1983. Bangladesh District Gazetteers: Tangail, Government of Bangladesh (GOB), Dhaka.12pp. 
Mukul, S. A.; Uddin, M. B.; Uddin, M. S. and Khan, M. A. S. A. 2007. Protected areas of Bangladesh. Current status and efficacy for biodiversity conservation. Unpublished manuscript.
Playfair, M. A. 1909. The Garos, 1st reprinted in 1975, Gauhati, India, United Publishers. Shiva, V. (1994) Close to Home: Women Reconnect Ecology, Health and Development, UK, Earthscan Publications Limited. 